\title{
THE MUSIC OF BARTOLOMEO MUTIS, CONTE DI CESANA
}

\author{
KATHARINA HAUN \\ Schola Cantorum Basiliensis, Basel
}

Izvleček: Bartolomeo Mutis, grof iz Cesane, je bil dvorni kaplan in pevec v glasbeni kapeli nadvojvode Ferdinanda v Gradcu. Leta 1613 je izšla njegova zbirka, v kateri je bilo kar štirinajst monodičnih skladb in malih duhovnih koncertov, in je ena od prvih takih zbirk, ki so izšle izven Italije. Mutisov slog je analiziran v primerjavi $z$ drugimi njemu sodobnimi glasbenimi viri.

Ključne besede: zgodnja monodija, Bartolomeo Mutis, italijanski dvorni glasbeniki v Avstriji.

\begin{abstract}
Bartolomeo Mutis, Conte di Cesana, was a court chaplain and singer in the court chapel of Archduke Ferdinand in Graz. In 1613 he published one of the first collections of monodies (numbering fourteen) and small-scale concertos by a composer living outside Italy. Mutis's compositional style is analysed and compared with that of contemporaries.
\end{abstract}

Keywords: early monody, Bartolomeo Mutis, Italian court musicians in Austria.

This article will present the sparse biographical details known for Mutis and introduce his collection of monodies and small-scale concertos. As examples, some of them will be analysed and compared with the sacred concertos he contributed to the Parnassus Musicus Ferdinandaeus, being examined in the light of the performance practice of the time. For this reason it will be put into context with the more well-known monodies by Giulio Caccini in Le nuove musiche and the statements from a letter by Luigi Zenobi from about 1600, in which he explains the qualities of a good musician. In addition Johann Andreas Herbst's Musica Prattica from 1653 will be looked at for diminution examples.

We know little about Bartolomeo Mutis, Conte di Cesana. ${ }^{1}$ Born into a noble family in the city of Belluno between 1575 and 1580, he came to the Graz court of Ferdinand II in 1604 . He was employed as the court chaplain and as a tenor singer. Next to these employments, he was most probably also almoner to Ferdinand's brother Archduke Maximilian Ernst, to whom Mutis' collection of monodies was dedicated. As an employee highly valued by the Imperial family, he accompanied Ferdinand's sister Constanze to her wedding with Sigismund III in Poland in 1605, and joined Ferdinand himself for the

1 Federhofer, Musikpflege, 185-187; Federhofer, "Mutis, Bartolomeo, Count of Cesana"; Grassl, "Mutis, Bartolomeo Conte di Cesana". 
wedding of King Matthias in Vienna in 1611. Mutis moved with the court to Vienna and died in 1623 or 1624 .

What makes him particularly interesting, however, is the fact that he was one of the first composers to publish a collection of monodies and small-scale madrigals while working outside of Italy.

In 1613 his Musiche a una doi et tre voci per cantare et sonare con chitarroni, overo con altri istromenti di corpo was printed in Venice. ${ }^{2}$ This comprises fourteen pieces and was dedicated to Archduke Maximilian Ernst. One of the pieces was composed by Mutis's colleague Francesco degli Atti, being the latter's only known composition. ${ }^{3}$

A facsimile of the collection made from the example in the Library of Congress can be found online ${ }^{4}$ and a modern edition of it has appeared in the series Denkmäler der Tonkunst in Österreich in a volume entitled Frühmeister des Stile Nuovo. ${ }^{5}$

In Musiche a una doi et tre voci we find two monodic pieces, six pieces for two equal voices and five for three voices. The monodies are in many ways comparable to Caccini's well-known pieces from Le nuove musiche. The duets are written in three different styles. Two of them are in a dialogue form. In "O come sei gentile" one of the voices represents a bird. In "Aminta tu" one of the voices poses questions and the second one responds. "Press'un fiume" is a villanella - a form with four stanzas that describe nature and in each verse oscillates between duple and triple meter and singing alternately and in thirds. The remaining three are mostly in thirds with some short passages where the two voices are imitating each other.

"Chi nutrisce", a terzetto, is in a similar style to that of the duets, with the tenor voice asking questions and the two sopranos responding in parallel thirds. The other four terzettos, for three unequal voices, are very madrigal-like, containing both homophonic and polyphonic passages.

Mutis' collection gives an overview of the types of secular songs of the time. The pieces are fairly simple in contrapuntal terms and show no real difficulties in regard to dissonances or unpredictable leaps or lines. As we will see shortly, Mutis was able to compose with more complexity, as becomes evident in his contributions to the Parnassus Musicus Ferdinandeus, but in his own collection he chose to practise greater restraint.

In order to evaluate the pieces in this collection fully, one has first to examine the sources of the time that discuss performance practice and musical quality. Luigi Zenobi, a famous cornetto player, who was employed at multiple courts in Europe in the course of his life, writes one of the sources to be looked at in this area. He was in the service of seeking singers to join the Ferrarese court in 1597 and was the singing teacher to Anna of Austria, daughter of Maximilian II. Zenobi was employed at Maximilian's court from 1569 to 1573 and was knighted probably by Rudolf II, which clearly links him to the Habsburg Empire and shows that his opinion on what makes a good musician is valued. Around

2 Mutis, Musiche.

3 Ibid., 161-162.

4 The Library of Congress, Music Division, Washington, D.C. (US-Wc), M1490.C35 M8: http:// lcweb2.loc.gov/diglib/ihas/loc.natlib.ihas.200154732/default.html.

5 Wessely, Frühmeister, 3-48. 
1600 he was asked multiple times by an unknown prince, what a perfect musician must be able to do and know. ${ }^{6}$ Zenobi's response is that a good singer must have a knowledge of counterpoint, sing very fast notes and cope with leaps in large and small note-values, syncopation mixed with artful dissonances, chromatics, proportions, musical signs and mensurations occurring in a composition. In addition to these practical skills, a singer, most importantly, must sing with good taste and grace and be able to express the words with his voice dynamically and with appropriate timbre. He must also be able to express the affect both with and without passaggi. Zenobi identifies a further quality: when encountering a mistake in the composition made by either the composer or a copyist, a singer should be able to improvise a correct counterpoint and find his way back into his own notated part. As the terminology for ornaments is very similar to the one Caccini uses in his preface to Le nuove musiche the two sources chosen to give contemporary context are also closely linked to one another.

Giulio Caccini's collection was well known then and is now. Many sources refer to his monodies and they are taken as a model by composers for writing monodies for the following decades after its printing in 1601. Looking at the main parameters such as print format, written-out passaggi and basso continuo parts, we find many similarities to Mutis' collection.

Mutis primary parameter in composing lies on expressing the words with the melodies and he does this in a very evident manner. He, like Giulio Caccini a few years before, puts the music as a servant to the words. Wide leaps, chromatic lines, syncopation, dissonances and proportions - the musical difficulties, that Zenobi mentions, a singer must know how to treat - occur from time to time but not constantly. He writes out some passaggi, to be sung in order to emphasize the important words in the text, but would certainly expect a singer to add more.

If we compare these pieces with Caccini's songs, we see that in Le nuove musiche the written-out passaggi use even shorter note-values, whereas Mutis keeps semifusae as his shortest notes. The bass line and the written-out groppi and cascati look very similar in the two collections being compared. Caccini pays more attention to the realization of the bass line, writing down numerals, while Mutis is content to write a sharp when he wants a major rather than a minor chord and only very rarely inserts a 6 to indicate a six-three chord. Both composers use texts that were well known and used by many composers of the time. ${ }^{7}$ The prints are in score and upright format, a common option for printed monodies in the first half of the seventeenth century. Besides Caccini's monodies, the collections Le varie musiche (1609) by Jacopo Peri and Le musiche da cantar solo (1609) by Sigismondo d'India are printed in that manner.

Looking further into detail at the songs "La misera farfalla" - one of the monodies and "Ah dolente Partita" - one of the three part madrigals - one can identify typical and atypical compositional details of Mutis and his time. Mutis's lyrics are often well-known

6 Blackburn and Lowinsky, "Luigi Zenobi”, 61-114.

7 Wessely, Frühmeister, V-VIII. 
texts. There are many madrigals set to the text of Battista Guarini's "Ah dolente Partita", including compositions by Claudio Monteverdi, Antonio Cifra, Stefano Bernardi and others. ${ }^{8}$

In these scores it is specified that either a cantus or a tenor can sing the upper part notwithstanding the uniform presence of the soprano clef. Such flexibility is typical for composers working outside Italy. Rasi, for example, prescribes the same option in his collection, ${ }^{9}$ whereas Caccini does not (although this naturally gives no indication that his pieces would not have been sung with "natural" male voices).

"La misera farfalla"10 is a text by Girolamo Casoni also used for example by Giovanni Croce in a five-part madrigal to be found in the Novi pensieri a cinque voci (Venice, 1594). In Mutis' composition, the story of the miserable butterfly is in D-Dorian. Already in the first phrase we can see that the emphasis and meaning of words are important to Mutis. In order to imitate the flutter of wings, the word "farfalla" never occurs without a passaggio. Likewise, the word "intorno" (bb. 15-17), ${ }^{11}$ meaning "around", is sung with passaggi in order to imitate a circling motion. When the words "volar" ("fly") and "scherzar" ("jest") appear, the bass moves more quickly, and there are more syllabically set notes, the composer's intention being to pack more text into a shorter length of time, thereby generating a feeling of energy and power (bb. 12-14).

\section{Music example 1}

Excerpt from page 3 of Musiche a una doi e tre voce (the Library of Congress, Music Division, Washington, D.C. [US-Wc], M1490.C35 M8; available online)

C

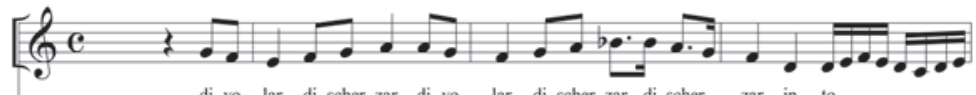

di vo - lar di scher-zar, di vo - lar di scher-zar, di scher - zar in to

bc
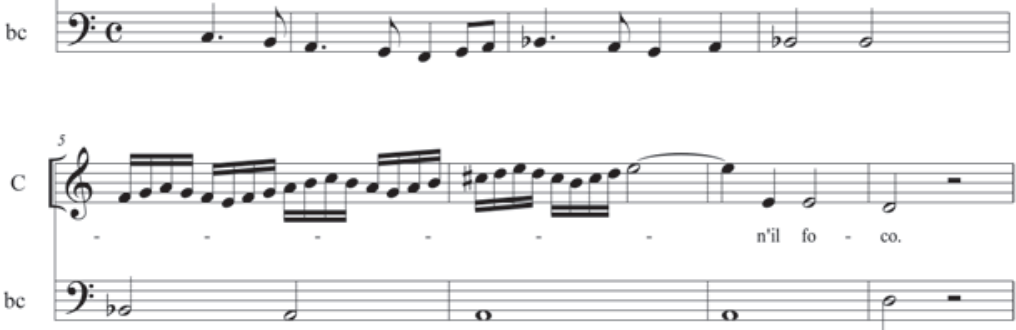

There are parallel fifths at the words "di volar" and "la terza" in the second part (bb. 26-27), which can easily be disguised via ornamentation. Even though these are obvious solecisms in formal contrapuntal terms, the lines in which they occur are written in a beautiful way. The third section of the text likens the singer to a butterfly that can fly merrily in the vicinity of a luminous gaze, but in the end will inevitably burn itself. This part reserves passaggi for the important words, but the affect itself - the sad conclusion that the

8 Ibid.

9 Rasi, Musiche da camera e da chiesa.

${ }^{10}$ Ibid.

${ }^{11}$ The bar numbers are referring to the edition by Wessely, Frühmeister. 
butterfly will in the end burn - is not expressed by harmony or melody and is therefore left for the singer to interpret. Mutis sets the phrase "di dover" (bb. 45-46), meaning "justly", plainly - in strong contrast to the final, heavily ornamented "scherzando" (bb. 42-44).

\section{Music example 2}

Excerpt from page 4 of Musiche a una doi e tre voce (as for music example 1)

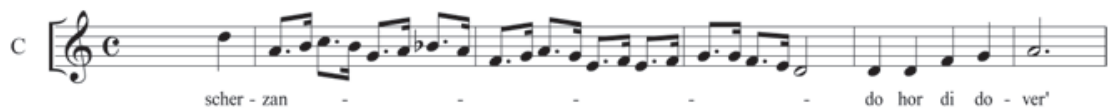

The singer should emphasize this contrast with additional passaggi, tremoli, trilli, effects of timbre, dynamics and rubato. Of course, all these techniques would have been expected of a singer of the time. Zenobis states: "He must use different passaggi in the same songs $[\ldots]$ when repeating the same thing he must always sing new ones. He must know how to sing the piece in its simple form, that is, without any passaggio, but only with grace, trillo, tremolo, ondeggiamento, and esclamatione."12

Caccini complains that the singers of his time overload pieces with passaggi, rendering the text incomprehensible, ${ }^{13}$ but at the same time points out where he wishes the singer to add passaggi, tremolo and trilli and to impart dynamic variety. Even the amount he suggests is more than most singers of today would venture to introduce. In many sources, including Caccini and Zenobi, the importance of employing diverse passaggi, and of being inventive, spontaneous and never repetitive is pointed out. Cadences, above all, should not remain unembellished. Since cadential ornamentation was so common, it did not necessarily have to be written out on paper. In the final cadence of the second part there is an unornamented Soprano Clausula, for which we find an abundance of possibilities in diminution treatises of the time. One might refer to examples by Johann Andreas Herbst that appear in his treatise Musica Prattica (1653), which was a well-known source in its day. Herbst was close in age to Mutis and his treatise is written to show "the Italian singing manner" to the Germans, which is therefore an important source for today's musicians to ornament music in the Italian style in the first half of the seventeenth century. On pages 59 and 60 he gives examples for a cadence in $d$, exactly like the one in the monody at hand. One can therefore simply take the exact passaggio Herbst suggests and sing it instead of the written part.

Returning to "La misera farfalla" and looking at the lines of fusae we have much evidence, that there should be variety in the way they were sung. Caccini suggests, as does Brunelli in Varii esercitii among others, that two fusae should not be sung with equal length, but instead in dotted or lombardic manner or something in between. He mentions

12 Blackburn and Lowinsky, "Luigi Zenobi", 101.

13 " [...] che non se ne intendeva parola per la multitude die passaggi, tanto nelle sillabe brevi quanto lunghe, et in ogni qualità di musiche [...]". Caccini, Le Nuove Musiche. 
the keyword "sprezzatura", which denotes a certain freedom and artful carelessness that one should apply to the music. ${ }^{14}$

\section{Music example 3}

Excerpts from pages 59 and 60 of the Musica Moderna Prattica (Bayerische Staatsbibliothek, Munich [D-Mbs], 4 Mus.th. 642)
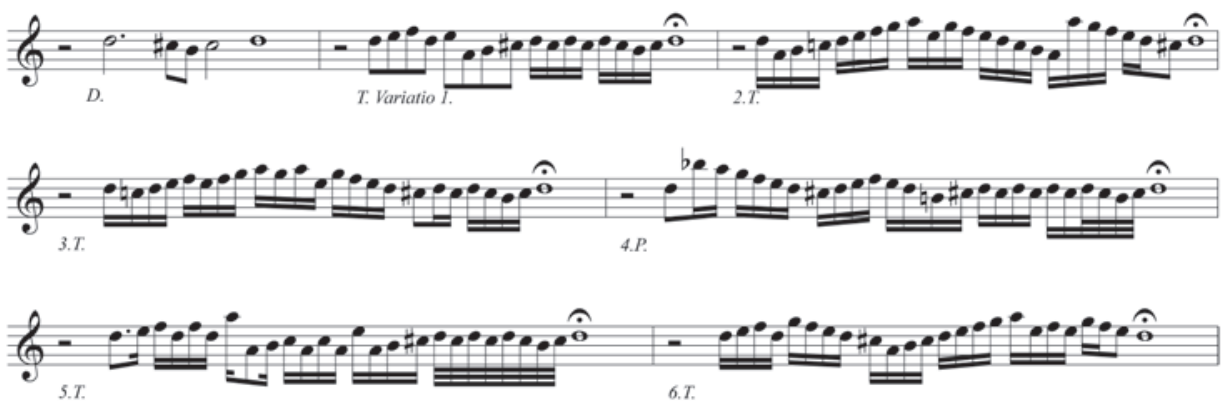

The treatment of dissonance in Mutis's solo and duet compositions is quite simple. There are passing notes and suspensions that resolve downwards. In his terzettos there is more frequent use made of dissonances, especially in "Ah dolente partita", where their presence is certainly related to the more tragic text. In the madrigal for "Canto, Alto e Basso" there is a 4-3 dissonance already on the second semibreve (b. 2) in order to emphasize the word "dolente" for the first time. The initial phrase of the piece in the transposed G-Dorian mode ends with a very typical cadential motion in $d$, where the soprano has a discant clausula, the alto a tenor clausula and the Basso generale a bass clausula (b. 6). Additionally, the short diminution for the first syllable of "partita" in the alto part constitutes a very typical progression exhibiting in written-out fashion the inequality of quavers mentioned earlier (b. 4).

\section{Music example 4}

Excerpt from page 29 of Musiche a una doi e tre voce (as for music example 1)

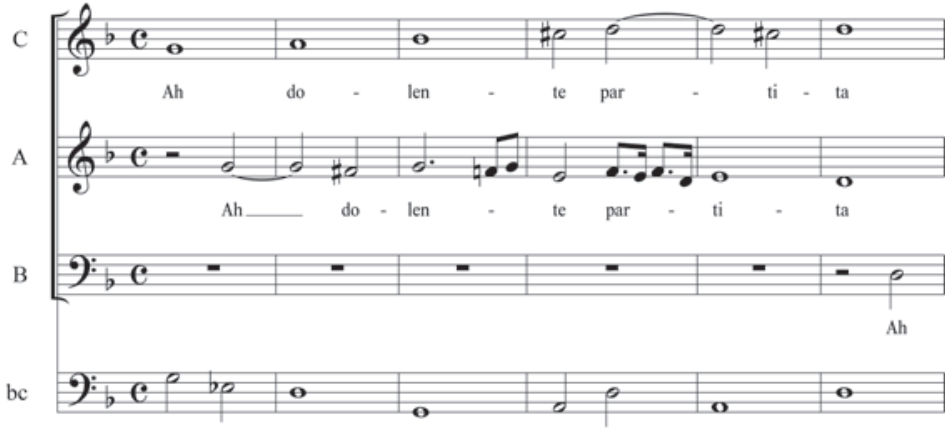

${ }^{14}$ This concept of "sprezzatura" comes from Baldassare Castiglione. Javitch, "Il Cortegiano", 319-328. 
The bass responds with the second line of text, including a long diminution on the word "vita" (bb. 8-9). Using rapid motion in semifusae on the words "e" and "i"" (bb. 27-29), the composer creates a feeling of agitation, before he returns to 6/4-suspensions (bb. 34-35) and 4/3 chains in combination with a bassus duriusculus (b. 38) to express "la morte" and "la pena".

\section{Music example 5}

Excerpt from page 29 of Musiche a una doi e tre voce (as for music example 1)
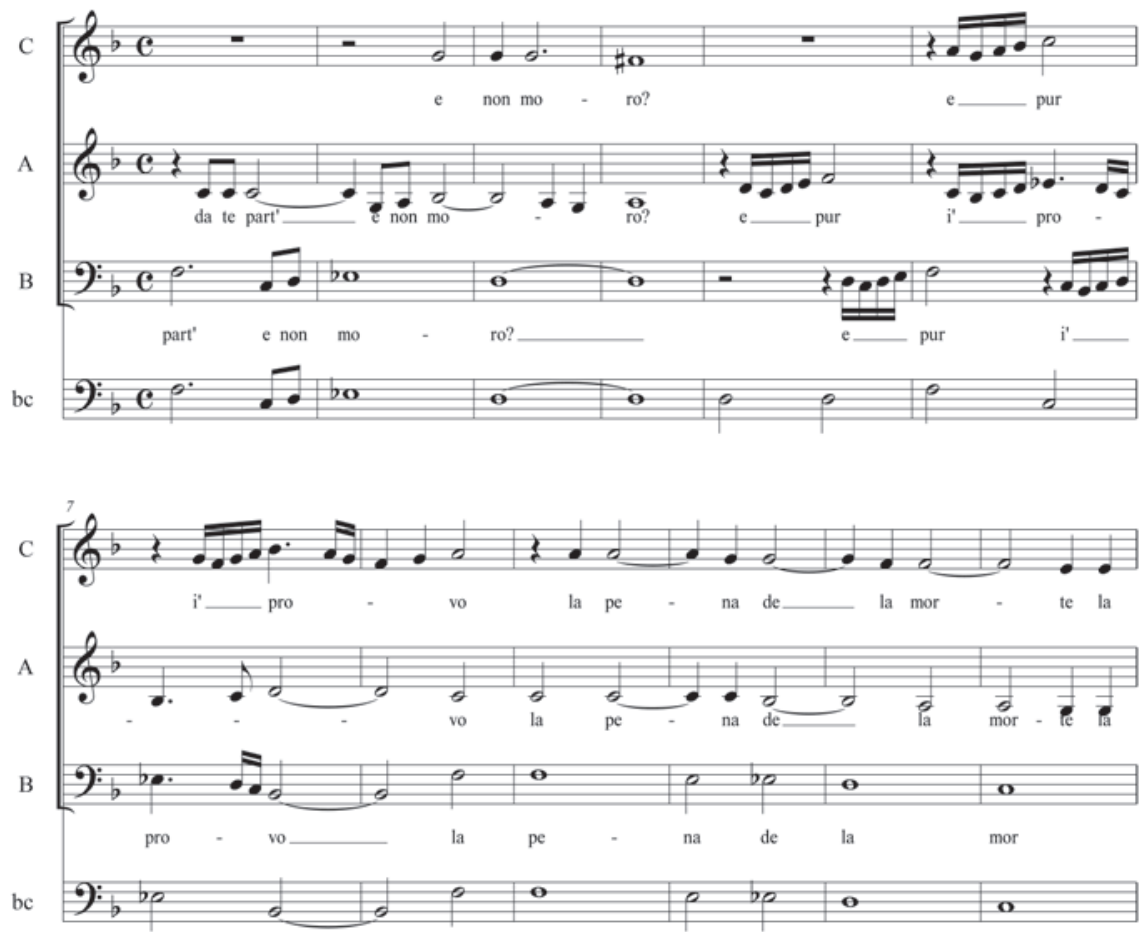

A short, homophonic phrase (bb. 42-43) introduces the next passage. The words "vivace morire" ("to die lively") are expressed with music written in fusae, which propel the text forward but do not align syllabically and frequently change chord, which creates a fast harmonic rhythm (bb. 45-46). In the following passage the harmonic rhythm decelerates once more, in order to give each part the opportunity for a downward scale on "immortalmente" (bb. 49, 51, 52, 54, 55 and 56). This resolves into a cadence featuring a discant clausula in the vocal bass line and a bass clausula in the Basso generale, which produces the only four-part cadence in the piece (bb. 57-58). 


\section{Music example 6}

Excerpt from page 30 of Musiche a una doi e tre voce (as for music example 1)

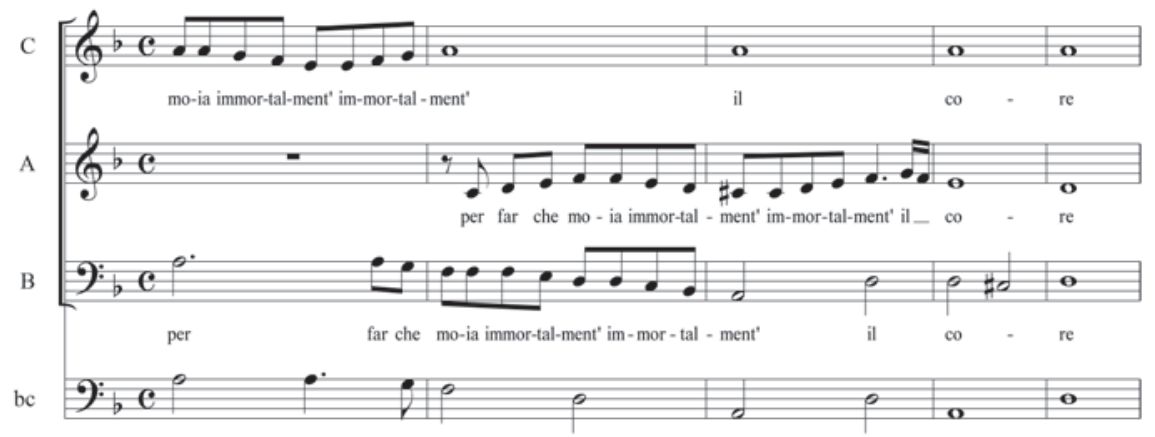

After repeating two phrases in exactly the same manner as before, Mutis writes eight consecutive semibreves on the pitch $d$ in the bass, while the two upper voices imitate one another with motives in D major an octave apart (bb. 67-74), before proceeding to a final $g$ cadence. This results in a very long penultimate chord, affording an opportunity for improvisation (in this case, written-out), just as almost all treatises of the time recommend. The very end of the cadence is once again unornamented, creating an opportunity for the musician.

\section{Music example 7}

Excerpt from page 31 of Musiche a una doi e tre voce (as for music example 1)
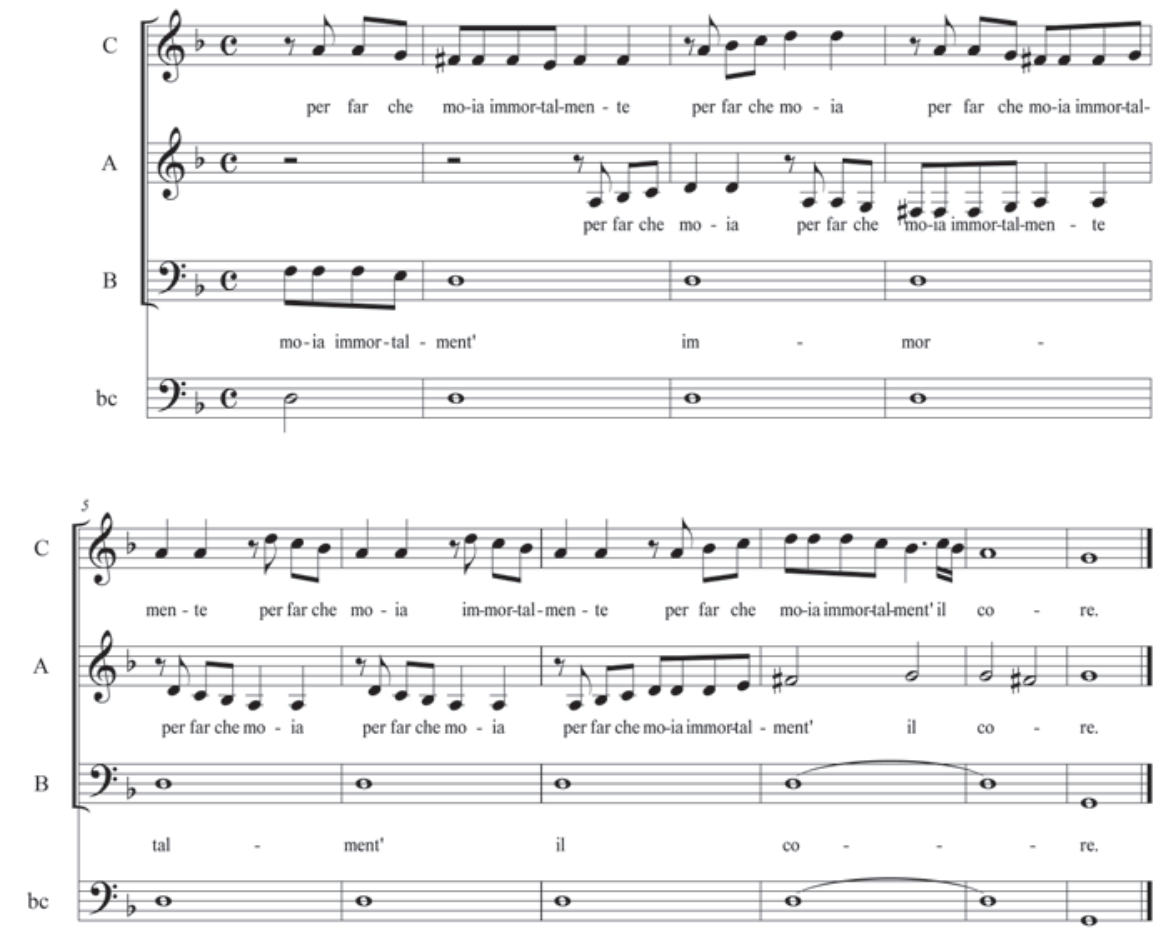
In both pieces tremoli, trilli and dynamic variety should be applied frequently - not in a spirit of pure decoration but rather as a means towards "grace". This gives an idea of how closely connected these devices were to the musical performance practice of the time. The affective impression of a performance should be treated as an absolute priority. This point is difficult, however, for modern audiences to grasp on account of its indefinable nature.

When one compares this collection with the two pieces that Mutis contributed to the Parnassus Musicus Ferdinandaeus, it seems obvious that the composer chose there to compose in a different style. As Zenobi puts it, "He must sing in one style in church, in another in the chamber, and in the third one in the open air". ${ }^{15}$ Because the Parnassus is a collection of sacred pieces and therefore has more profound topics informing the music, Mutis composes with more dissonances and a more sophisticated counterpoint. The lines are less stereotyped in contour, and there is supplementary numerical figuring in the bass.

In "Quemadmodum desiderat", a motet for "Canto e Basso", some interesting dissonances already appear in the first three bars. The soprano enters on a dissonance, then creates another one two bars later, where a major seventh moves initially to an augmented sixth and is only then resolved.

\section{Music example 8}

Bars 1-6 from "Quemadmodum desiderat" from the Parnassus Musicus Ferdinandaeus

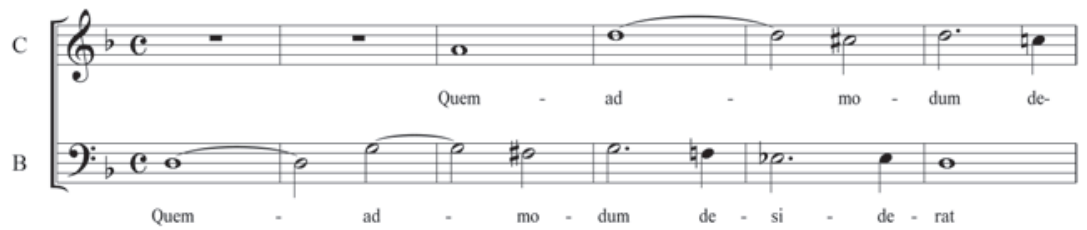

The next two phrases begin with leaps. On the whole, Mutis employs more leaps than steps and introduces many dissonant passing notes, which lends an over-arching morbid character to the piece. He uses both dotted and lombardic rhythms: something observable less frequently in his collection of madrigals, where a singer might be expected to introduce such rhythms anyway without a need to express them in notation. Speaking more generally, we encounter an unusual manner of constructing the counterpoint, since even though the setting is polyphonic, the parts very often do not imitate each other at all. Another very interesting section follows. On the word "lacrimae" the bass leaps down a diminished fourth and lands a tritone away from the soprano. This dissonant interval resolves a semiminima later, but the progression nevertheless violates every principle of voice leading.

${ }^{15}$ Blackburn and Lowinsky, "Luigi Zenobi”, 101-102 


\section{Music example 9}

Bars 53-55 from "Quemadmodum desiderat" from the Parnassus Musicus Ferdinandaeus

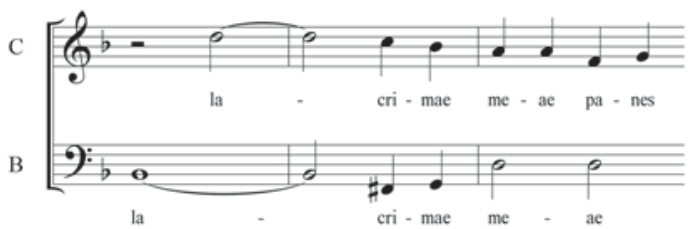

A few notes later the soprano leaps down a minor sixth and goes to the tritone, before this interval resolves to a perfect fifth. The next section, in triple metre, is unusual because the bass part includes syncopated notes, a rare feature. Syncopated basses normally appear only in conjunction with dance-like forms that are homophonic or at least simple in structure. Immediately after a return to quadruple metre we have close-knit polyphony, which creates an agitated mood. In the last part of the piece Mutis displays an up-to-date approach by writing an independent instrumental bass line for the soprano solo, even allowing the continuo part to play the soprano motive twice in pre-imitation. Mutis adds passaggi in the affective phrases of the concluding section and ends on a final cadence in $g$.

Other than the aforementioned collection and Mutis' contribution to the Parnassus, there is no further evidence of compositions by him that have been preserved. Research in the different libraries in- and outside of Austria had no result in that regard.

The pieces we have prove that Mutis' style was very much up to the standard of his contemporaries. The variety of sacred and secular small-scale concertos and monodies gives a good overview of the genres at the beginning of the seventeenth century. The many similarities it has to Caccini's songs, the connections we find to Zenobi's letter and the possibilities to insert Herbst's examples of diminution give us an idea of how to interpret such pieces without tending to judge the mere melody and bass line written on the piece of paper. Only by following the instructions of the time about diminution, interpretation and grace, we have a chance to recreate what might have been performed four hundred years ago.

\section{Bibliography}

Bonometti, Giovanni Battista, ed. Parnassus musicus Ferdinandaeus. Venice: Giacomo Vincenti, 1615.

Blackburn, Bonnie J., and Edward Lowinsky. "Luigi Zenobi and his Letter on the Perfect Musician”. Studi Musicali 22, no. 1 (1993): 61-114.

Brunelli, Antonio. Varii Esercitii, 1614. Edited by Richard Erig. Italienische Diminutionslehren, 2. Zürich: Musikverlag zum Pelikan, 1977.

Caccini, Giulio. Le Nuove Musiche: Giulio Caccini; Riproduzione dell'edizione del 1601.

Edited by Francesco Mantica. Prime fioriture del melodramma italiano, 2. Rome: Raccolte Claudio Monteverdi, 1930. 
Federhofer, Hellmut. "Graz Court Musicians and their Contributions to the 'Parnassus Musicus Ferdinandaeus' (1615)”. Musica Disciplina 9 (1955): 167-244.

___ Musikpflege und Musiker am Grazer Habsburgerhof der Erzherzöge Karl und Ferdinand von Innerösterreich. Mainz: B. Schott's Söhne, 1967.

___ "Mutis, Bartolomeo, Count of Cesana". In Grove Music Online. Accessed 18 September, 2017.

Grassl, Markus. "Mutis, Bartolomeo Conte di Cesana". In: MGG Online, edited by Laurenz Lütteken. Accessed 18 September 2017.

Herbst, Johann Andreas. Musica Moderna Prattica, overo maniera di buon canto. 2nd ed. Frankfurt: Antonius Hummen, 1653.

Javitch, Daniel. "Il Cortegiano and the Constraints of Despotism". In The Book of the Courtier, by Baldassare Castiglione, edited by Daniel Javitch, translated by Charles S. Singleton, 319-328. Norton Critical Editions. New York: Norton, 2002.

Rasi, Francesco. Musiche da camera e chiesa, 1612. Edited by Herbert Seifert. Denkmäler der Musik in Salzburg, 7. Salzburg: Selke Verlag, 1995.

Wessely, Othmar, ed. Frühmeister des Stile nuovo in Österreich. Denkmäler der Tonkunst in Österreich, 125. Graz: Akademische Druck- u. Verlaganstalt, 1973.

- Das Werden der barocken Musikkultur. In Musikgeschichte Österreichs, vol. 1, Von den Anfängen zum Barock, 2nd ed., edited by Rudolf Flotzinger, 253-297. Vienna: Böhlau Verlag, 1995. 


\section{GLASBA BARTOLOMEA MUTISA, GROFA IZ CESANE}

\section{Povzetek}

Le malo je znanega o prvem skladatelju, ki je izven Italije objavil zbirko monodičnih skladb. Bartolomeo Mutis, grof is Cesane se je rodil med 1575 in 1580 . Leta 1604 so ga najeli za kaplana in pevca v dvorni glasbeni kapeli nadvojvode Ferdinanda II. v Gradcu. Kot cenjen član te dvorne ustanove je bil leta 1605 v spremstvu Ferdinandove sestre, ki se je poročila na dvor poljskega kralja Sigismunda III., pozneje leta 1611 pa je bil tudi v spremstvu nadvojvode, ko se je na Dunaju udeležil poroke bratranca nadvojvode Matije Avstrijskega. Mutis je umrl na Dunaju leta 1623 kot član Ferdinandove cesarske dvorne kapele.

Še preden je prispeval dva moteta v antologijo Parnassus musicus Ferdinandeus (1615), je leta 1613 izdal svojo zbirko posvetnih pesmi Musiche a una, doi et tre voci per cantare et sonare con chitaroni, overo con altri istromenti di corpo. To je bila prva zbirka, ki je vsebovala tudi monodične skladbe, in je izšla izven Italije. Posvečena je nadvojvodi Maximilianu Ernstu in vsebuje 14 posvetnih skladb. V razpravi so obravnavane tri skladbe: enoglasna La misera farfalla in triglasna Ah dolente partita iz zbirke Musiche a una, doi et tre voci in motet Quemadmodum desiderat iz antologije Parnassus. Skladbe so analizirane in primerjane s sodobnimi viri, kot je zbirka Le nuove musiche Giulia Caccinija, teoretskim Pismom o popolnem glasbeniku Luigija Zenobija in primeri iz traktata Musica practica Johanna Andreasa Herbsta.

Mutisov slog se v obeh zvrsteh - posvetna pesem in duhovni motet - bistveno razlikuje. V posvetni glasbi po uporabi disonanc in v motetih po kompleksnejšem kontrapunktu. Najpomembnejši zunanji vpliv za kompozicijo predstavlja pomen besedila. Z izpisanimi pasažami, različnimi načini uglasbitve besed (silabičnih in polifonih delov) ustvarja učinkovito posvetno monodijo in monodični motet. V kadencah pogosto ne izpisuje diminucij, kar izvajalcem daje proste roke pri lastnem improviziranju, ki je bilo $\mathrm{v}$ času renesanse in zgodnjega baroka povsem ustaljena praksa.

Zbirka Musiche a una, doi et tre voci Bartolomea Mutisa prinaša pregled raznih posvetnih zvrsti svojega časa, od monodij, vilanel, polifonih madrigalov do dramatskih skladb v obliki dialoga $\mathrm{v}$ preprostem kontrapunktu. Nedvomno je od pevcev pričakoval dobro mero improvizacije z uporabo različnih diminucij, okraskov in rubatov, ki so sodili v novi slog zgodnjega 17. stoletja. $Z$ ozirom na jasne napotke omenjenih virov o izvajalni praksi si je lahko predstavljati, kaj se je od tedanjih izvajalcev pričakovalo in koliko svobode tudi današnja historična izvajalna praksa pušča glasbenikom, od katerih se pričakuje mnogo več, kot je zapisanega v notah. Oboje skupaj pa je treba upoštevati pri slogovni analizi zgodnje monodije. 